\title{
QIYAS SEBUAH METODE PENGGALIAN HUKUM ISLAM
}

\author{
Fathurrahman Azhari \\ Fakultas Syariah dan Ekonomi Islam IAIN Antasari, Jl. Jenderal Ahmad Yani Km 4,5 Banjarmasin
}

e-mail:

\begin{abstract}
Abstrak: Dalam hukum Islam, qiyas adalah sebuah solusi yang ditawarkan untuk berbagai kasus hukum yang tidak disebutkan secara eksplisit dalil dalam sumber hukum Islam. Diketahui bahwa Imam Syafi'i adalah penggagas konsep qiyas. Dalam pandangannya, berbagai kasus hukum yang terdapat dalam masyarakat Muslim yang tidak jelas diatur dalam al-Qur'an atau Sunnah dapat diselesaikan melalui qiyas, baik dalam bentuk qiyas jaly atau qiyas khafi. Semua orang mengetahui bahwa hukum Islam terkandung dalam Al-Quran, tradisi kenabian, pendapat dari generasi awal ulama, konsensus dan kontroversi di antara mereka, memiliki kapasitas intelektual yang tinggi dan analisis yang tajam di mana ia dapat mengidentifikasi fakta yang tidak jelas, dan bisa menjadi al-Qais. Konsep qiyas terdiri dari empat elemen al-ashl yaitu hukum asli yang berasal dari teks, al-far, atau dari sebuah al-' illah. Sebuah qiyas tidak boleh melampaui teks dari sumber utama hukum Islam, karena diambil dari teks yang ada.
\end{abstract}

Abstract: As an Islamic law argument, qiyas is a solution to various legal cases which are not explicitly mentioned in religious texts. Imam Syafi'i is the initiator of the concept of qiyas. In his view, various legal cases found in Muslim society which are not obviously regulated in religious texts can be solved through qiyas, either in the form of strong qiyas or weak qiyas. Anybody who knows Arabic, Islamic law contained in the Quran, the prophetic tradition, the opinions of the early generation of the ulama, consensus and controversies among them, having high intellectual capacity and sharp analysis in which he or she can identify obscured facts, can become an al-qais. the qiyas should consist of four elements the al-ashl, the original law derived from the text, the al-far', an the legal al-illah. An qiyas should not go beyond relegious texts, because it is merely an exension of them.

Kata kunci: qiyas, nas, ashal, far', illah dan hukum.

\section{Pendahuluan}

Dikalangan ulama tidak ada perbedaan pendapat dalam menerapkan qiyas untuk hal-hal yang bersifat duniawi, tetapi berbeda pendapat dalam lapangan syar'i. Jumhur ulama, memandang qiyas sebagai dalil hukum yang dijadikan salah satu metode istinbath hukum Islam. Terkecuali kelompok al-Nazhzham, Dawud al-Zhahir, Syi'ah Imamiyah tidak mengakuinya qiyas sebagai metode istinbath hukum. ${ }^{1}$ Menurut Nasrun Haroen, Jumhur ulama ushul fiqh berpendirian bahwa qiyas bisa dijadikan sarana sebagai metode istinbath hukum, bahkan lebih dari itu, Syari' menuntut pengamalan qiyas. $^{2}$

Jumhur ulama menjadikan qiyas sebagai metode istinbath hukum Islam, adalah sebagai pengamalan terhadap teks Al-Quran pada surah An-Nisa ayat 59 yang memerintahkan apabila

\footnotetext{
1 Muhammad bin Ali al-Syaukani, Irsyad al Fubul ila tahqiq al-haq min 'ilmi ushul, (Beirut: Dar al-Fikr, t.th), hlm. 199-200.

2 Nasrun Haroen, 1999, hlm. 65.
}

ditemui suatu peristiwa atau kasus yang tidak didapat hukumnya dalam kitab Allah dan sunnah Rasul Muhammad Saw., agar merujuk (dikembalikan) kepada Al-Quran dan Sunnah. Karena itu penggunaan qiyas dalam istinbath hukum merupakan bagian yang esensial dalam pembahasan ilmu ushul fiqh.

Membicarakan tentang qiyas sebagai metode istinbath hukum Islam tidak bisa terlepas dari salah satu bagian esensial dalam pembentukannya, yaitu tentang illat hukum. Oleh karena itu, pengetahuan tentang cara menemukan illat hukum sangat diperlukan. Sebab pembentukan qiyas ditentukan oleh ada dan tidak adanya 'illat hukum.

\section{Pengertian Qiyas}

Qiyas menurut bahasa yaitu التقدير للثيئ بما يمانله artinya menetapkan bagi sesuatu dengan apa yang semisalnya. Misalnya seseorang mengukur kain dengan meteran sama dengan ukuran kain yang lain. Abu al-Husain al-Bashri (w. $436 \mathrm{H}$ ) merumuskan qiyas itu adalah: 


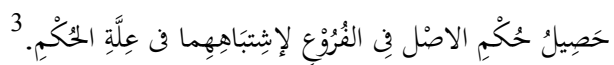
Menerapkan bukum yang terdapat pada ashl (pokok) kepada fara' (cabang), karena terdapat kesamaan 'illat bukum antara keduanya.

Selain rumusan pengertian qiyas di atas, masih banyak pengertian yang dirumuskan oleh usbuliyyin. Bertolak dari pengertian tersebut, maka qiyas itu yaitu:

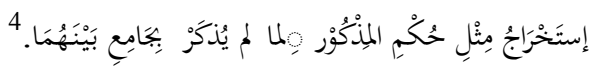

Upaya mengeluarkan bukum atas sesuatu yang belum ada bukumnya sebanding dengan sesuatu yang ada bukumnya, dengan memperhatikan kesamaan alasan (illat) antara keduanya.

Berdasarkan pengertian qiyas di atas, maka apabila ada suatu kasus yang hukumnya telah ditetapkan dalam suatu nas dan 'illat hukumnya telah diketahui menurut cara-cara me ngetahui 'illat hukum, kemudian didapat pula suatu kasus lain yang hukumnya tidak ditetapkan oleh suatu nas, tetapi 'illat hukumnya adalah sama dengan iillat hukum dari kasus yang telah memiliki nas tersebut, maka hukum kasus yang tidak ditetapkan oleh nas itu disamakan dengan hukum kasus yang telah ada nasnya, sebab adanya persamaan' illat hukum pada kedua kasus itu.

\section{Rukun-Rukun Qiyas}

Dari pengertian qiyas di atas, dapat diketahui, bahwa ada empat unsur (rukun) dalam qiyas. Keempat rukun atau unsur qiyas tersebut adalah:

1. Harus ada pokok (الأصل), yaitu persoalan yang telah dijelaskan ketentuan hukumnya di dalam nash. Pokok ini sering pula disebut dengan " yakni yang menjadi tempat sandaran qiyâs, dan kadang-kadang disebut pula dengan "المشبـه بـه" menjadi tempat penyamaan sesuatu.

2. Adanya cabang (الفرع), yaitu persoalan atau perkara baru yang tidak ada nash yang menjelaskan hukumnya dan ia akan disamakan hukumnya dengan pokok.

3. Adanya ketetapan hukum asal (الحكم الأصلى) yang telah dijelaskan oleh nash pada pokok.

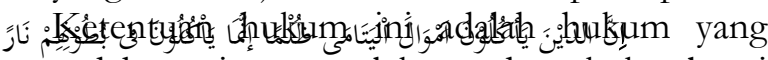
sudah pasti yang melekat pada pokok sebagai tempat penyandaran kesamaan hukum bagi cabang.

4. Adanya illat (العلة), yakni suatu sifat atau keadaan yang menjadi alasan/dasar penetapan hukum pada pokok dan 'illat ini juga terdapat

$3 \quad$ Ibid, hlm. 198.

4 Ibid, hlm.198. pada cabang yang akan dicari hukumnya. Tllat ini harus jelas, relatif dapat diukur dan kuat dugaan bahwa dialah yang menjadi alasan penetapan hukum Allah dan Rasul-Nya. ${ }^{5}$

\section{Bentuk-Bentuk Qiyas}

Qiyas dilihat dari bentuknya dibagi kepada tiga macam, yaitu: Qiyas 'illat; Qiyas dalalab; dan Qiyas syibh.

1. Qiyas 'illat, ialah qiyas yang mempersamakan ashl dengan $f a r$ karena keduanya mempunyai persamaan 'illat. Qiyas 'illat terbagi:

a. Qiyas jaly, yaitu qiyas yang 'illatnya berdasarkan dalil yang pasti, tidak ada kemungkinan lain selain dari 'illat yang ditunjukkan oleh dalil itu. Qiyas jaly terbagi kepada:

1). Qiyas yang 'illatnya ditunjuk dengan kata-kata, seperti memabukkan adalah 'illat larangan minum khamar,yang disebut dengan jelas dalam nas.

2). Qiyas aulawi. Ialah qiyas yang hukum pada far' sebenarnya lebih utama ditetapkan dibanding dengan hukum pada ashl. Seperti haramnya hukum mengucapkan kata-kata "ah" kepada kedua orang tua. Al-Quran surah al-Isra ayat 23 :

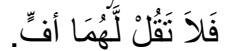

"Maka janganlah ucapkan kata-kata "ab" kepada kedua orangtua(mu)."

Berdasarkan firman Allah SWT di atas, 'illatnya ialah menyakiti perasaan kedua orangtua. Bagaimana hukum memukul orang tua? Dari kedua peristiwa nyatalah bahwa perasaan orang tua lebih sakit bila dipukul anaknya dibanding dengan ucapan "ah" yang diucapkan anaknya kepadanya. Karena itu sebenarnya hukum yang ditetapkan bagi far' lebih utama dibanding dengan hukum yang ditetapkan pada ashl.

3). Qiyas musawi, yaitu, qiyas hukum yang ditetapkan pada $f a r^{\prime}$ sebanding dengan hukum yang ditetapkan pada ashl, seperti menjual harta anak yatim diqiyaskan kepada memakan harta anak yatim. 'Illatnya ialah sama-sama menghabiskan harta anak yatim. Memakan harta anak yatim haram hukumnya berdasarkan firman Allah SWT dalam surah an-Nisa ayat 10 :

"Sesungguhnya orang-orang yang memakan harta anak yatim secara aniaya, ia tidak. lain banyalab menelan api neraka ke dalam perutnya."

Karena itu ditetapkan pulalah haram hukumnya menjual harta anak yatim. Dari kedua peristiwa

5 Lihat: Alyasa Abubakar, Hukum Islam di Indonesia, hlm. 179. 
ini nampak bahwa hukum yang ditetapkan pada ashl sama pantasnya dengan hukum yang ditetapkan pada far'.

b. Qiyas Khafy, yaitu qiyas yang 'illatnya mungkin dijadikan 'illat dan mungkin pula tidak dijadikan 'illat, seperti mengqiyaskan sisa minuman burung kepada sisa minuman binatang buas. "Illatnya ialah kedua binatang itu sama-sama minum dengan mulutnya, sehingga air liurnya bercampur dengan sisa minumannya itu. 'Illat ini mungkin dapat digunakan untuk sisa burung buas dan mungkin pula tidak, karena mulut burung buas berbeda dengan mulut binatang buas. Mulut burung buas terdiri dari tulang atau zat tanduk. Tulang atau zat tanduk adalah suci, sedang mulut binatang buas adalah daging, daging binatang buas adalah haram, namun kedua-duanya adalah mulut, dan sisa minuman. Yang tersembunyi di sini ialah keadaan mulut burung buas yang berupa tulang atau zat tanduk.

2. Qiyas Dalalah, yaitu qiyas yang 'illatnya tidak disebut, tetapi merupakan petunjuk yang menunjukkan adanya 'illat untuk menetapkan sesuatu hukum dari suatu peristiwa. Seperti harta kanak-kanak yang belum baligh, apakah wajib ditunaikan zakatnya atau tidak. Para ulama yang menetapkannya wajib mengqiyaskannya kepada harta orang yang telah baligh, karena ada petunjuk yang menyatakan 'illatnya, yaitu kedua harta itu sama-sama dapat bertambah atau berkembang. Tetapi Madzhab Hanafi, tidak mengqiyaskannya kepada orang yang telah baligh, namun kepada ibadah, seperti shalat, puasa dan sebagainya. Ibadah hanya diwajibkan kepada orang yang mukallaf, termasuk di dalamnya orang yang telah baligh, tetapi tidak diwajibkan kepada anak kecil (orang yang belum baligh). Karena itu anak kecil tidak wajib menunaikan zakat hartanya yang telah memenuhi syarat-syarat zakat.

3. Qiyas Syibh, yaitu qiyas yang far' dapat diqiyaskan kepada dua ashl atau lebih, tetapi diambil ashl yang lebih banyak persamaannya dengan far'. Seperti hukum merusak budak dapat diqiyaskan kepada hukum merusak orang merdeka, karena kedua-duanya adalah manusia. Tetapi dapat pula diqiyaskan kepada harta benda, karena sama-sama merupakan hak milik. Dalam hal ini budak diqiyaskan kepada harta benda karena lebih banyak persamaannya dibanding dengan diqiyaskan kepada orang merdeka. Sebagaimana harta, budak dapat diperjualbelikan, diberikan kepada orang lain, diwariskan, diwakafkan dan sebagainya.

\section{Cara Menemukan 'Illat Hukum}

Tllat menurut bahasa berarti sakit, penyakit. Bisa pula berarti sebab atau karena. ${ }^{6}$ Para Ushuliyyin memberikan pengertian terhadap 'illat, yaitu sifat yang ada pada ashl yang sifat itu menjadi dasar untuk menetapkan hukum ashl serta untuk mengetahui hukum pada far' yang belum ditetapkan hukumnya.

Adanya 'illat hukum itu sangat penting dan menentukan, untuk dapat diterapkannya suatu qiyas. Suatu kesimpulan tidak dapat ditarik secara qiyas, jika tidak ada persamaan antara 'illat pada kasus yang satu dengan kasus yang lain.

Untuk mencari 'illat, dilakukan beberapa cara, yaitu:

1. Nas yang menunjukkan, dalam hal ini nas sendiri yang menunjukkan bahwa suatu sifat merupakan 'illat hukum dari suatu kasus. 'Illat yang demikian disebut 'illat manshush 'alaibi. Petunjuk nas tentang illat hukum ada dua macam, yaitu; sharahah dan isyarah atau 'ima.

a. Dalalah sharahah, yaitu penunjukkan lafazh yang terkandung dalam nas kepada Dalalah sharahab 'illat hukum jelas sekali, karena lafaz̧ nas itu sendiri yang mennjukkan illat hukumnya dengan jelas. Dalalah sharahah ada yang qath'i (pasti) dan ada yang zhanni (dugaan kuat).

Dalalab sharahah yang qath'i, apabila penunjukkannya secara pasti terhadap illat hukum. Misalnya firman Allah dalam surah AnNisa ayat 165:

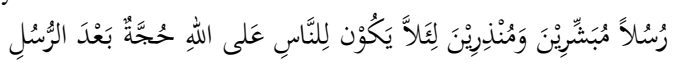

(Mereka Kami utus) selaku rasul-rasul pembawa berita gembira dan pemberi peringatan agar supaya tidak ada alasan bagi manusia membantah Allah sesudab diutusnya rasul-rasul itu.

"Li'alla yakuna" dan "ba'da al-Rasul" merupakan illat hukum yang pasti, tidak mungkin dialihkan kepada yang lain yang zhanni, apabila penunjukkan nas kepada illat hukum berdasarkan dugaan yang kuat, karena kemungkinan dapat dibawa kepada 'illat hukum yang lain. Misalnya al-Qur'an dalam surah al-Isra ayat 78 :

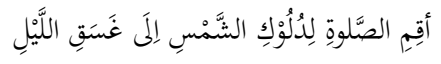

Dirikanlah shalat, karena matahari tergelincir sampai gelap malam...

6 Muhammad bin Idris, al, Marbawi, Qamus al-Marbawi, Surabaya, al-Hidayah, t.th. hlm. 38. 
Huruf "lam" pada kalimat "liduluki" adalah memiliki arti "disebabkan" atau "karena" dan dapat pula berarti "setelah". Tetapi menurut dugaan yang kuat jika huruf "lam" itu diartikan dengan "karena" maka akan memperjelas maksud dari ayat tersebut.

b. Dalalah Isyarah atau "ima, adalah petunjuk yang dipahami dari sifat yang menyertainya. Jika penyertaan sifat itu tidak dapat dipahamkan, maka tidak ada gunanya menyertakan sifat itu. Misalnya al-Qur'an dalam surah al-Baqarah ayat 222:

$$
\text { وَلاَ تَقَرَبُوْهُهنَّ حَتَّى يَطْهُرْنَ... }
$$

Dan janganlah kamu mendekati mereka sehingga mereka suci...

Pada ayat di atas diterangkan bahwa "kesucian" merupakan batas ('illat) kebolehan suami mencampuri isterinya. Dengan demikian, dalalab isyarah atau 'ima pada ayat di atas adalah membedakan antara dua hukum dengan batasan (ghayah).

2. Ijma' yang menunjukkan, maksudnya bahwa 'illat itu ditetapkan dengan ijma'. Misalnya belum baligh menjadi 'illat dikuasainya oleh wali harta anak yang belum dewasa. 'Illat ini disepakati leh para ulama.

3. Dengan penelitian/ijtihad, yaitu illat yang diketahui melalui penelitian atau ijtihad, adalah 'illat yang diketahui melalui empat cara, yaitu. Pertama, al-Munasabah atau takbrij alManath, Kedua, Tahqiq al-Manath, Ketiga, tanqih al-Manath, dan Keempat, al-Sabru wal al-Taqsim.

Al-Munasabah, yaitu persesuaian antara sesuatu hal, keadaan atau sifat dengan perintah atau larangan. Yang termasuk munasabah adalah; Memelihara agama (atTaubah ayat 29), Memelihara jiwa (al-Baqarah ayat 179), Memelihara akal (al-Maidah ayat 91), Memelihara keturunan (an-Nur ayat 1-3) dan Memelihara harta benda (al-Baqarah ayat 275). Kelima hal ini adalah termasuk dharury.

Adapun pada tingkatan hajjy, baik dalam bidang ibadah maupun muamalah. Dalam bidang ibadah dibolehkannya mengqadha puasa Ramadhan bagi orang yang musafir, sedangkan dalam bidang muamalah misalnya bolehnya jual beli salam. Hal yang termasuk tingkatan baijy ini adalah sebagai pelengkap untuk kesempurnaan masalah dharury.

Sedangkan pada tingkatan tabsiny, adalah perhiasan baik dalam ibadah maupun dalam muamalah, seperti berpakaian rapi dalam beribadah, dan menghindari jual beli bernajis dalam muamalah.

Tahqiq al-Manath, yaitu menetapkan illat hukum pada ashl, maksudnya sepakat menetapkan 'illat pada ashl, baik berdasarkan nas atau tidak, kemudian illat itu disesuaikan dengan 'illat far'. Misalnya 'illat potong tangan bagi pencuri, yaitu mengambil barang orang lain secara sembunyi pada tempat penyimpanannya, hal ini sepakat para ulama. Tetapi jika diterapkan pada far', yaitu hukuman pencuri kain kafan dalam kubur. Maka menurut ulama Malikiyah dan Syafi'iyah, pencuri tersebut potong tangannya, sedangkan menurut ulama Hanafiyah tidak dipotong tangannya, karena ia tidak dapat dikatakan pencuri.

Tanqih al-Manath, yaitu mengumpulkan sifatsifat yang ada pada $a s h l$ dan sifat-sifat yang ada pada far', kemudian dicari sifat-sifat yang sama. Sifat-sifat yang sama itulah dijadikan illat hukum. Sedangkan sifat-sifat yang berbeda ditinggalkan. Tllat semacam ini diketahui setelah illat tersebut muncul lewat penalaran akal, sehingga disebut pula illat almustanbathah. Untuk itu diperlukan suatu proses tersebut, dengan tiga tahap.

a. tahap identifikasi 'illat

b. tahap seleksi 'illat

c. tahap penetapan 'illat.

Contohnya adalah penetapan illat wali dalam akad nikah. Tahap pertama adalah takbrij 'illat, yang mengidentifikasi seluruh hal yang berkaitan dengan perempuan yang harus ada walinya, meliputi jenis kewanitaannya, kelemahannya, kedudukannya sebagai anak yang belum dewasa atau sudah dewasa, statusnya sebagai wanita yang belum kawin atau sudah kawin. Setelah itu melangkah ke tahap kedua tanqih 'illat, yakni menyeleksi satu persatu hal-hal tersebut, maka ditemukan sebagai berikut:

a. jenis kewanitaan saja tidak dapat menjadi 'illat karena tidak semua wanita diharuskan punya wali dalam nikahnya.

b. kelemahan wanita juga tidak menjadi illat wali dalam akad nikah, karena wanita yang kuat pun harus dinikahkan oleh walinya.

c. kedudukan sebagai anak juga tidak menjadi 'illat, baik dewasa ataupun anak-anak, karena terkadang yang menjadi wali itu bukan bapak, melainkan saudara laki-laki atau paman. 
d. status wanita yang belum kawin inilah yang menjadi 'illat.

Setelah menempuh seleksi 'illat di atas, proses berikutnya ialah tahqiq 'illat (pengukuhan 'illat) dengan menetapkan satu hal yang menjadi illat setelah menyeleksi hal-hal yang diduga menjadi 'illat, yang terseleksi haruslah memiliki semua cirri-ciri:

a. Merupakan sifat dasar sesuai dengan tabiat dan esensinya.

b. Sesuatu yang bersifat nyata, jelas dan tidak boleh yang samar-samar atau tersembunyi.

c. Ada kesesuaian, yakni sifat 'illat itu relevan dengan persoalan yang tengah di bahas hukumnya.

d. Berada pada posisi yang paling kuat di antara segala hal yang diduga sebagai 'illat.

Pada contoh kasus di atas, yang menjadi 'illat wali dalam akad nikah adalah status kewanitaan yang belum kawin, karena di antara semua hal yang disebutkan satu-satunya hal yang memiliki kesesuaian ciri-ciri secara kolektif adalah status sebagai wanita yang belum kawin.

Al-Sabru wa al-Taqsim, yaitu meneliti kemungkinan-kemungkinan sfat-sifat pada suatu kasus, kemudian memisah-misah di antara sifatsifat itu, yang paling tepat dijadikan sebagai 'illat hukum. al-Sabru wa al-Taqsim dilakukan apabila ada nas yang menerangkan tentang suatu kasus, tetapi tidak ada nas yang menerangkan 'illatnya. Misalnya Sunnah Nabi Saw. tentang harta ribawi:

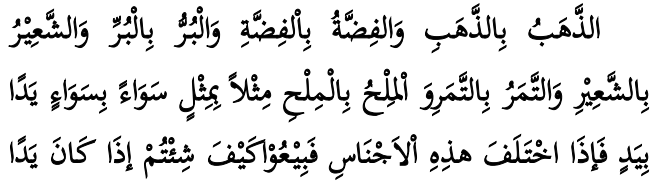

Emas dengan emas, perak dengan perak, gandum dengan gandum, padi dengan padi, kurma dengan kurma, garam dengan garam, hendaklah sama jenisnya, sama ukurannya lagi kontan, apabila berbeda jenisnya, maka juallab menurut kehendakmu, bila bal itu dilakukan dengan kontan (H.R Muslim).

Rasulullah Saw., berdasarkan Sunnah di atas, menetapkan haramnya riba fadl, tetapi tidak ada nas yang lain atau ijma' yang menetapkan 'illat. Para mujtahid mencari sifat-sifat dari enam macam yang disebutkan dalam Sunnah itu, kemudian menetapkan sifat yang sama yang patut dijadikan 'illat. Maka yang diperoleh hanya satu sifat yang dipunyai oleh enam macam tersebut, yaitu sifat yang dapat dipastikan dengan ukurannya baik timbangan atau takaran. Dengan demikian, para ulama menetapkan 'illat riba fadl adalah ukuran yaitu takaran atau timbangan.

\section{Pembagian 'Illat}

Ditinjau dari segi ketentuan pencipta hukum (syari') tentang sifat apakah sesuai atau tidak dengan hukum, maka ulama Ushul Fiqh membaginya kepada empat bagian, yaitu:

1. Munasib mu'tsir, yaitu persesuaian yang diungkapkan oleh syara' dengan sempurna, atau dengan perkataan lain bahwa pencipta hukum (syari') telah menciptakan hukum sesuai dengan sifat itu, seperti firman Allah SWT dalam al-Quran surah al-Baqarah ayat 222:

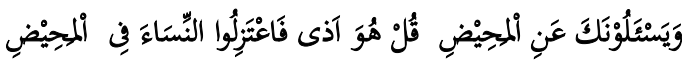

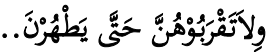

"Mereka bertanya kepadamu tentang haid, katakanlah haid itu adalah suatu kotoran. Oleh sebab itu bendaklah kamu menjaubkan diri dari wanita di waktu haid."

Pada ayat di atas Allah SW'T (sebagai syari) telah menetapkan hukum, yaitu haram mencampuri isteri yang sedang haid. Sebagai dasar penetapan hukum itu ialah kotoran, karena kotoran itu dinyatakan dalam firman Allah SWT di atas sebagai 'illatnya. Kotoran sebagai sifat yang menjadi sebab haram mencampuri isteri yang sedang haid adalah sifat yang sesuai dan menentukan penetapan hukum.

2. Munasib mulaim, yaitu persesuaian yang diungkapkan syara' pada salah satu jalan saja. Maksudnya ialah persesuaian itu tidak diungkapkan syara' sebagai 'illat hukum pada masalah yang sedang dihadapi, tetapi diungkapkan sebagai 'illat hukum dan disebut dalam nash pada masalah yang lain yang sejenis dengan hukum yang sedang dihadapi. Contohnya, ialah kekuasaan wali untuk mengawinkan anak kecil yang di bawah perwaliannya tidak ada nas yang menerangkan 'illatnya. Pada masalah lain yaitu pengurusan harta anak yatim yang masih kecil, syara' mengungkapkan keadaan kecil sebagai 'illat hukum yang menyebabkan wali berkuasa atas harta anak yatim yang berada di bawah perwaliannya itu. Berdasarkan pengungkapan syara' itu maka keadaan kecil dapat pula dijadikan 'illat untuk menciptakan hukum pada masalah lain, seperti penetapan kekuasaan wali dalam mengawinkan anak yatim yang berada di bawah perwaliannya. 
3. Munasib mursal, yaitu munasib yang tidak dinyatakan dan tidak pula diungkapkan oleh syara'. Munasib mursal berupa sesuatu yang nampak oleh mujtahid bahwa menetapkan hukum atas dasarnya mendatangkan kemaslahatan, tetapi tiada dalil yang menyatakan bahwa syara' membolehkan atau tidak membolehkannya, seperti membukukan al-Qur'an atau mushhaf, tidak ada dalil yang membolehkan atau melarangnya. Tetapi Khalifah Utsman bin Affan melihat kemaslahatannya bagi seluruh kaum muslimin, yaitu Al-Qur'an tidak lagi berserakan karena telah tertulis dalam satu buku serta dapat menghindarkan kaum muslimin dari kemungkinan terjadinya perselisihan tentang dialek al-Qur'an .

4. Munasib mulghaa, yaitu munasib yang tidak diungkapkan oleh syara' sedikitpun, tetapi ada petunjuk yang menyatakan bahwa menetapkan atas dasarnya diduga dapat mewujudkan kemaslahatan. Dalam pada itu syara' tidak menyusun hukum sesuai dengan sifat atau 'illat tersebut, bahkan syara' memberi petunjuk atas pembatalan atas sifat tersebut. Sebagai contohnya, ialah kedudukan laki-laki dan perempuan dalam kerabat. Kemudian atas dasar persamaan itu mungkin dapat ditetapkan pula persamaan dalam warisan. Tetapi syara' mengisyaratkan pembatalannya dengan menyatakan bahwa bagian laki-Iaki adalah dua kali bagian perempuan.

\section{Aplikasi 'Illat Terhadap Perubahan Hukum Fikih}

Allah dalam memberi khitab kepada mukallaf yang berupa hukum termuat dalam nas selalu mengandung 'illat dan hikmah hukum. Oleh karena itu para ulama ushul fikih membuat suatu Qaidah Fiqbiyyah yang berbunyi bahwa :

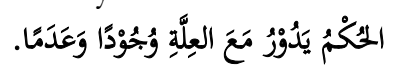

Hukum itu berputar bersama illatnya dalam mewujudkan dan meniadakan bukum.

Illat hukum itu selalu sesuai dengan hikmah hukum, hikmah itulah yang menjadi tujuan disyariatkannya hukum. Oleh karena itu sesuatu yang di nilai sebagai 'illat suatu hukum apabila terjadi munasabah dengan hikmah, tetapi illat itu akan tertolak, jika 'illat itu tidak munasabah dengan hikmah hukum.

Dalam nas, bagi pencuri yang memenuhi persyaratan budud sanksinya adalah dipotong tangan. Hukuman ini termaktub dalam surah alMaidah ayat: 38 .

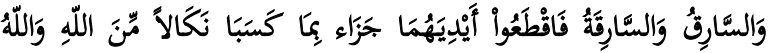

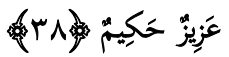

Laki-laki yang mencuri dan perempuan yang mencuri, potonglah tangan keduanya (sebagai) pembalasan bagi apa yang mereka kerjakan dan sebagai siksaan dari Allah. Dan Allab Maba Perkasa lagi Maba Bijaksana.

Pada nas tersebut, jelas illat dari hukum potong tangan adalah "pencurian". Dihukum potong tangan bagi pencuri sesuai dengan hikmah hukum yaitu terpelihara harta manusia (bifdhul mal). Begitu pula hukuman qishah bagi pembunuhan secara sengaja. ${ }^{7}$ yaitu pembunuh yang tidak dimaafkan oleh pihak keluarga korban hukuman baginya dibunuh (qishas/setimpal) illat hukumnya adalah pembunuhan sengaja, sesuai dengan hikmah hukumnya, yaitu terpelihara nyawa manusia. Hukuman dera delapan puluh kali dera bagi penuduh zina (had qadhaf) 8 'illat hukumnya adalah penuduhan yang telah memenuhi persyaratan budud sesuai dengan hikmah hukum akan pentingnya memelihara kehormatan orang lain. Keringanan bagi orang melakukan perjalanan (musafir) untuk meng-qashr shalat (meringkas jumlah rakaat shalat yang empat menjadi dua rakaat ${ }^{9}$ yang 'illat hukumnya adalah melakukan

7 Al-Baqarah ayat 108 :Hai orang-orang yang beriman, diwajibkan atas kamu qishash berkenaan dengan orang-orang yang dibunuh; orang merdeka dengan orang merdeka, hamba dengan hamba dan wanita dengan wanita. Maka barangsiapa yang mendapat suatu pema'afan dari saudaranya, hendaklah (yang mema afkan) mengikuti dengan cara yang baik, dan hendaklah (yang diberi ma`af) membayar (diat) kepada yang memberi ma af dengan cara yang baik (pula). Yang demikian itu adalah suatu keringanan dari Tuhan kamu dan suatu rahmat. Barangsiapa yang melampaui batas sesudah itu, maka baginya siksa yang sangat pedih.

8 An-Nur ayat 4 : Dan orang-orang yang menuduh wanita-wanita yang baik-baik (berbuat zina) dan mereka tidak mendatangkan empat orang saksi, maka deralah mereka (yang menuduh itu) delapan puluh kali dera, dan janganlah kamu terima kesaksian mereka buat selama-lamanya. Dan mereka itulah orang-orang yang fasik.

9 An-Nisa ayat 101: Dan apabila kamu bepergian di muka bumi, maka tidaklah mengapa kamu menqashar sembahyang(mu), jika kamu takut diserang orang-orang kafir. Sesungguhnya orangorang kafir itu adalah musuh yang nyata bagimu. 
perjalanan mengandung hikmah menghindari kesukaran (masyaqqah). Dengan demikian illat hukum itu bersesuaian dengan hukum, dan hikmah dari pensyariatan adalah untuk mewujudkan kemaslahatan dan menolak kemudaratan.

Apakah suatu hukum dalam fikih dapat terus berlaku sepanjang masa, dan ataukah dapat berubah. Hukum yang diperoleh dengan ijtihad baik hasil dari interpretasi 'illat yang ditunjuk oleh nas maupun yang tidak ditunjuk oleh nas ada kemungkinan untuk terjadinya perubahan. Perubahan hukum fikih disebabkan oleh tiga hal yaitu: 1). Interpretasi tentang illat hukum itu sendiri yang berubah sesuai dengan perkembangan pemahaman terhadap petunjuk nas yang menjadi landasannya; 2). Ketentuan fikih yang telah berlaku diubah menjadi ketentuan fikih yang lain untuk mewujudkan tujuan illat pensyariatannya. ${ }^{10} 3$ 3). Dan hukum fikih menjadi luas karena illat sebagai porosnya diperluas (kondisi, sifat dan ukurannya) sedangkan nama illat yang diperluas tersebut tidak berubah.

1. Sesuatu yang selama ini dianggap sebagai 'illat hukum dalam fikih, akan tetapi seiring dengan berkembang pemahaman terhadap dalil nas landasannya ditemukanlah 'illat hukum fikih yang lain. Sebagai contohnya adalah interpretasi tentang illat zakat hasil pertanian/tanaman. Yang biasa diinterpretasi sebagai illatnya adalah makanan pokok, dapat disimpan lama, dapat ditimbang atau ditakar, atau hasil dari tanaman yang ditanam. Akan tetapi, sekarang para ulama lebih populer dengan pendapat bahwa 'illat tersebut adalah produktif (al-nama). Jadi, semua tanaman yang produktif wajib dikeluarkan zakatnya. ${ }^{11}$

2. Ketentuan hukum fikih yang telah berlaku diubah menjadi ketentuan hukum fikih yang lain untuk mewujudkan tujuan 'illat pensyariatannya. Untuk memelihara tujuan syariat, suatu ketentuan hukum yang telah diberlakukan berdasarkan atas illat syariat diubah dalam bentuk ketentuan hukum yang lain. Contohnya pembagian tanah fay' di Irak

$10 \mathrm{Al}$ Yasa Abubakar, Tesis: Metode Istinbath Fiqib di Indonesia (Kasus-Kasus Majelis Muzakarah Al Az̧ar), (Yogyakarta: IAIN Sunan Kalijaga, 1987), hlm. 4445.

11 Al Yasa Abubakar, Hukum Islam Di Indonesia Pemikiran Dan Praktek, Pengantar Juhaya S. Praja, (Bandung: Rosda Karya, 1991), hlm. 181. pada masa khalifah Umar bin Khattab r.a. yang 'illat pembagiannya adalah agar tidak menjadi monopoli orang-orang kaya saja ${ }^{12}$ Pada masa Rasul, kebun-kebun orang Yahudi yang kalah perang di Madinah dan Khaibar dibagi bagikan kepada kaum muslimin. Tetapi Umar r.a, tidak mau membagi lahan lahan pertanian di Irak yang demikian subur dan luas setelah selesai perang. Ijtihad Umar r.a., pembagian itu akan melahirkan sekelompok orang kaya baru yang justru dihindari oleh alQuran. Tanah tersebut harus jadi milik Negara dan disewakan kepada penduduk. Hasil sewa inilah yang dibagikan kepada orang orang yang tidak mampu dan pihak pihak yang memerlukan bantuan keuangan dari Negara. Perubahan hukum pembagian harta fay' tersebut dilakukan oleh Umar bin Khattab r.a. tetap mendasari atas illat pembagian harta fay' pada masa Rasulullah Saw. yaitu harta fay' jangan terpusat pada orang-orang kaya.

Peristiwa hukum fikih pada masa Umar r.a. sebagaimana yang tersebut di atas jika dirincikan yaitu: 1). 'Illat membagikan harta fay': agar tidak menjadi harta yang dimonopoli oleh orang orang kaya; 2). Bentuk pelaksanaan hukum masa Rasulullah: harta fay' dibagikan langsung kepada orang Islam; 3). Bentuk pelaksanaan hukum masa Umar r.a.: harta fay' tidak dibagikan secara langsung kepada orang Islam tetapi harta tersebut dikelola oleh Negara dan hasilnya dibagikan kepada orang yang tidak mampu dan kepada orang yang memerlukan keuangan dari Negara.

3. Ketentuan hukum fikih menjadi luas karena illat yang mendasari atasnya diperluas baik dalam aspek kondisi, sifat dan ukurannya sedangkan illat tersebut namanya tidak berubah. Cotohnya, tentang penerima zakat, ulama dahulu cenderung berhenti pada penggunaan metode bayani (memahami secara bahasa) semata, dan jika dikaitkan dengan realita sekarang beberapa golongan penerima

12 Al-Hasyr ayat 7: Harta rampasan fay' yang diberikan Allah kepada Rasul-Nya (yang berasal) dari penduduk beberapa negeri, adalah untuk Allah, Rasul, kerabat (Rasul), anak-anak yatim, orang-orang miskin dan untuk orang-orang yang dalam perjalanan, agar harta itu jangan hanya beredar di antara orang-orang kaya saja di antara kamu. Apa yang diberikan Rasul kepadamu maka terimalah. Dan apa yang dilarangnya bagimu maka tinggalkanlah. Dan bertakwalah kepada Allah. Sungguh, Allah sangat keras hukuman-Nya. 
zakat tidak ditemukan lagi. Misalnya golongan riqab. Riqab yang populer dipahami adalah pembebasan budak. Perbudakan secara harfiah (seperti masa feodal dahulu) pada masa modern telah dihapuskan sehingga secara resmi tidak ada lagi. Akan tetapi jika diperhatikan secara seksama, perilaku yang mencerminkan keadaan perbudakan masih nampak sampai sekarang. Oleh sebab itu, untuk mewujudkan tujuan syariat, menalar tentang riqab sebagai 'illat penerima zakat adalah sebuah keharusan bagi fukaha masa kini.

Untuk menemukan riqab dalam konteks sekarang ini, pendekatan multidisipliner adalah cara yang harus dilakukan oleh para mujtahid. Fakta menunjukkan, orang-orang yang hidup dalam "belenggu" pihak lain karena kontrak kerja atau orang-orang yang "ditawan dan dipaksa melakukan sesuatu yang tidak sah" yang sekarang disebut dengan "trafficking" masih ada. Berdasarkan fakta tersebut, keberadaan riqab sebagai illat penerima zakat masih ada sampai sekarang, jika fakta-fakta tersebut secara kebiasaan dikategorikan sebagai bagian dari praktek perbudakan. ${ }^{13}$ Dari contoh ini, jika korban trafficking dan orang yang hidup dalam belenggu orang lain karena kontrak kerja seperti para Tenaga Kerja Indonesia (TKI) di luar negeri dikatagorikan sebagai budak meskipun sistem perbudakannya tidak sama dengan perbudakan masa feodal, maka 'illat pentasyrian-nya masih tetap namanya yaitu membebaskan budak (riqab), akan tetapi cakupan illatnya yang berubah yaitu para korban trafficking dan para TKI di Negara asing. Maksudnya hukumnya adalah, jika cakupan iillat tersebut diberlakukan maka anggaran untuk pembebasan korban trafficking dan TKI yang ditindas oleh majikan di negeri orang bisa diambil dananya dari zakat. ${ }^{14}$

Ada 'illat hukum yang namanya masih tetap namun ukurannya berubah Mengenai illat hukum ini salah satu contoh nya adalah illat kebolehan qashar (meringkas) shalat yang empat rakat menjadi dua rakaat yaitu safr (orang yang melakukan perjalanan) ${ }^{15}$ Selama ini ukuran

13 Jabbar Sabil. Menalar Hukum Tuhan, (Banda Aceh: LKAS, 2009), hlm. xxiii

14 Dana zakat yang dihimpun oleh Badan Amil Zakat.

15 An-Nisa ayat 101 : 101. Dan apabila kamu bepergian di muka bumi, maka tidaklah mengapa kamu menqashar sembahyang(mu), jika kamu takut diserang orang-orang kafir. Sesungguhnya orangorang kafir itu adalah musuh yang nyata bagimu. perjalanan sebagai illatnya diukur berdasarkan atas "jarak tempuh". Jarak tempuh yang membolehkan qashar shalat adalah jarak tempuh dua marbalah, sama dengan empat barid, sama dengan 16 farsakh (satu farsakh sama dengan tiga mil dan satu mil sama dengan 12.000 kaki), yaitu perjalanan satu hari satu malam secara terus menerus, atau dua hari satu malam sekiranya beristirahat pada malam hari. Dengan ukuran kita sekarang jarak tempuh tersebut adalah sekitar 80 $\mathrm{km} .{ }^{16}$ Untuk masa kini alat transportasi yang sudah beragam dengan kecepatan yang sangat cepat (pesawat terbang, kereta api cepat, mobil dan lain-lain) dibanding dengan alat tansportasi masa Rasulullah Saw. (unta, kuda, keledai) mungkin ukuran perjalanan sebagai íllat kebolehan qasr shalat akan lebih tepat kalau jarak perjalanannya diukur dengan "waktu tempuh". Perjalanan yang membolehkan qasr shalat adalah perjalanan yang memakan waktu selama satu hari satu malam jika perjalanannya tanpa istirahat, atau satu hari dua malam jika perjalanan tersebut dilakukan ada istirahat diperjalanan. ${ }^{17}$

\section{Kesimpulan}

Berdasarkan uraian di atas, maka dapat disimpulkan, bahwa qiyas adalah Menerapkan hukum yang terdapat pada ashl (pokok) kepada far' (cabang), karena terdapat kesamaan 'illat hukum antara keduanya. Qiyas sebagai metode penggalian hukum Islam sangat tergantung dengan 'illat hukum. Untuk mengetahui 'illat hukum dilakukan beberapa cara, yaitu: Pertama, nas yang menunjukkan 'illat hukum. Kedua, ijma' dan ketiga,dengan penelitian/ijtihad. 'Illat hukum itu dalam pembagiannya, yaitu; Munasib mu'tsir, Munasib mula'im, Munasib mursal, Munasib mulghaa. Meskipun qiyas sebagai salah satu metode penggalian hukum Islam, tetapi para ulama masih berselisih pendapat dalam kehujjahannya. Jumhur ulama menjadikannya buijah dalam penggalian hukum Islam, sedangkan ulama al-Nazhzham, Dawud al-Zhahir, Syi'ah Imamiyah tidak mengakuinya.

\section{Daftar Pustaka :}

Abu Bakar, Syamsuddin Abu Abdillah Muhammad Ibn al-Qayyim al-Jauziyah, I'lamul Muwaqqïn an-Rabbil Alamin, Beirut: Daru al-Jail, t.th.

\footnotetext{
16 Jabbar, Op.Cit hlm. xx.

17 Ibid, hlm. xxi
} 
Abubakar, Al Yasa, Tesis: Metode Istinbath Fiqih di Indonesia (Kasus-Kasus Majelis Muzakarah Al Azhar), Yogyakarta: IAIN Sunan Kalijaga, 1987.

Hukum Islam Di Indonesia Pemikiran Dan Praktek Pengantar Jubaya S. Praja, Bandung: Rosda Karya, 1991.

Abu Dawud, Sulaiman bin Asy'ats, Sunan Abu Dawnd, Mekkah, Dar al-Baz, t.th.

Abu Zahrah, Muhammad, al Imam, Ushul Figh, Beirut, Dar al-Fikri, 1958

Amidi, al, al-Ihkam fi Ushûl al-Abkam, Qahirah, Muwassasah al-Halabi wa al-Syirkah li alNasyr wa al-Tauzy', t.th.

A. Rahman, Asymuni, Qawaid al-Fiqhiyyah, Jakarta, Bulan Bintang, 1976

Bakri, Asafri Jaya, Konsep Maqashid al-Syari'ah alSyatibi, Jakarta PT. Grafindo, 19961

Baihaqi, al-Hafizh Abu Bakar Ahmad bin Husain, al, Sunan Kubra, Beirut, Daru alMa'arif, t.th.

Bukhari, Imam Abi Abdillah Muhammad bin Ismail, al, Shahih al-Bukhari, Mesir, Dar alFikri, t.th.

Darul Quthni, al-Hafizh Ali bin Umar, Sunan Darul Quthni, Beirut, Dar al-Ma'arif, t.th.

Departemen Agama, Al-Qur'ân dan Terjemahnya, Jakarta, Proyek Pengadaan Kitab Suci AlQur'ân, 1984.

Filsafat Hukum Islam, Jakarta, Proyek Pembinaan Prasarana dan Sarana PT. IAIN, Binbaga Islam, 1987.

Din, Zaky. al, Ushûl Fiqh al-Islamy, Mesir, Darul Ta'lif, 1965.

Ghazali, Muhammad bin Muhammad, al, alMushtashfa min 'Ilmi al-Ushul, Beirut, Dar alFikri, t.th.

Hakim, Muhammad Taqi, al, al-Ushôl al Ammah li al-Figh al-Muqaran, Beirut, Daru al-Anshari, 1963.

Hasballah, Ali, Ushôl al-Tasyri' al-Islamy, Mesir, Darl Ma'arif, 1971

Hasan, M. Ali, Perbandingan Mað̧ab, (Jakarta: RajaGrafindo Persada, 1998), h. 190.

Ishfahani, al-Raghib, al-Mu'jam Mufradat al Fazh Al-Qur'ân Beirut, Daru al-Fikri, 1392.

Khallaf, Abd al-Wahhab, Ilmu Ushûl Figh, Kuwait, Daru al-Qalam, 1402

Khudary Bek, Muhammad, Ushûl Fiqh, ti. Zaid H. Al-Hamid, Pekalongan, Raja Murah, 1982

Mahmassani, Sobhi, Falsafat al-Tasyri' fi al-Islamy, tj. Ahmad Sadjono, Bandung, PT. Ma'arif, 1981
Manzur, Lisan al-'Arab, Beirut, Darul al-Shadr, t.th.

Marbawi, Muhammad bin Idris, al, Qamus alMarbawi, Surabaya, al-Hidayah, t.th.

Muhammad bin Ali bin al-Thaib, Abi al-Hasan, al-Mu'tamad fi Ushul al-Figh, Beirut, Dar alKutub al-Ilmiyyah, t.th.

Munawwar, Warson, al, Kamus al-Munawwar, Surabaya, Pustaka Progresif, 1984.

Muslim, al-Imam Abi Husain Muslim bin Hajjaj bin Muslim al-Qusyairi, Shabib Muslim, Mesir, Dar al-Fikri, 1996

Muzeid, Kamus Istilah Fiqh, Jakarta, Pustaka Firdaus, 1994.

Razy, Fakhruddin, al, al-Mabshul fi 'Ilmi al-Ushul, Beirut, Dar al-Kutub al-Ilmiyyah, 1999.

Sabil, Jabbar, Menalar Hukum Tuban, Banda Aceh, LKAS, 2009.

Syaukani, Muhammad bin Ali, Irsyad al-Fubul ila Tahqiq al-Haqq min 'Ilmi al-Ushul, Beirut, Dar alFikri, t.th.

Syafi'i, Muhammad bin Idris, al-Imam, al-Umm, Beirut, Daru al-Fikri, t.th.

Pustaka Firdaus, 1992 al-Risalah, Jakarta,

Syafi'i Rahmat, Ilmu Ushûl Fiqh, Bandung, CV. Pustaka Setia, 1999

Syatibi, Abu Ishaq Ibrahim bin Yusuf, al, alMuwafaqat fi Ushûl al-Syar'iyyah, Beirut, Dar al-Ma'arif, 1975

Thabari, Imam Abu Ja'far Muhammad bin Jarir al, Ikhtilaf al-Fuqaha, Beirut, Dar al-Kutub al-Ilmiyyah, t.th.

Tirmizi, Abu Isa Muhammad bin Isa Surah, at, Sunan al-Tirmizi, Mesir, Daru al-Fkri, 1988

Ibnu Majah, al-Hafizh Abi Abdillah Muhammad bin Yazid al-Quzwini, Sunan Ibnu Majah, Mesir, Daru al-Fikri, 1995

Ibnu Hazm, al-Ibkam fi Ushul al-Abkam, Beirut, Daru al-Kutub al-Ilmiyyah, t.th.

,Mulakhasah Ibtal al-Qiyas wa alRa'y wa al Istibsan wa al-Taqlid wa al-Ta'lil. Damsyik, Jami'ah Damsyik, 1960.

Ibnu Qayyim al-Jauziyah, I'lamu al Muwaqqi'in, Beirut, Dar al-Fikri, 1397 H.

Ifriqi, Ibnu Manzhur, Lisan al-Arab, Beirut, Dar al-Fikri, t.th

Yahya, Muktar dan Fatchur Rahman, Dasar Dasar Pembinaan Hukum Figh Islam, Bandung, PT. Al-Ma'arif, 1997.

Zuhaili, Wahbah, al, al-Figh al-Islamy wa Adillatubu, Damsyiq, Dar al-Fikri, 2002

Damsyiq, Dar al-Fikri, 1406 H. 
